\title{
Madzhab Fiqh dan Kedaulatan Ummat (Memahami Ikhtilâf dalam Bingkai Syarî'ah)
}

\author{
Abdul Mukti Thabrani \\ (Dosen Jurusan Syariah STAIN Pamekasan, Alumni Islamic University of \\ Madinah)
}

\begin{abstract}
Abstrak :
Tulisan ini berupaya memotret perbedaan pendapat (ikhtilâf) yang sarat dengan pertentangan (khilâf) dan mendudukkan keduanya dalam porsi dan proporsi yang sebenarnya, selaras dengan nafas Syarî'ah Islâm yang memandang ikhtilâf sebagai sebuah keniscayaan sejarah dan kebutuhan mendasar bagi dinamika internal sebuah ajaran yang penuh "rahmat" dan "fitrah". Ijtihâd fuqahâ' yang mengejawantah dalam aliran-aliran dan madzhab-madzhab figh, adalah tuntutan zaman yang dikukuhkan kewajibannya oleh Islâm sebagai sebuah produk persemaian 'aqlî dan naqlî demi kemaslahatan ummat Islâm sepanjang masa.
\end{abstract}

Kata kunci:

madzhab, fuqahâ', ikhtilâf, dan ijtihâd.

\section{Pendahuluan}

Ummat Nabî Muhammad SAW. pada awalnya hidup dalam pola kesatuan manhâj ibadah yang sederhana dan cukup terbuka, sebagaimana digambarkan sendiri oleh Nabî kal jasad al wâhid, sebagai satu bangunan raga yang merasakan sakit jika ada bagian lain yang sakit. ${ }^{1}$ Lalu generasi pertama ini pun menyebar ke seluruh penjuru dunia untuk menyebarkan syarî'ah Islâm, dengan al-Qur'ân dan alSunnah sebagai pijakan utamanya. Jika ada perselisihan dan perbedaan pendapat - hal yang sangat langka terjadi - rujukannya adalah petuah Nabî kepada Muadz bin Jabal ketika diangkat sebagai

1 Lihat Imâm Muslim, Shahîh Muslim, vol. 2 (Kairo: Dâr al-Salam, 1987), hlm. 342. 
utusan khusus ke Yaman, yaitu al-Qur'ân, al-Sunnah, dan ijtihâd ketika persoalan tidak ter-cover di dalam keduanya².

Seiring perjalanan waktu, persoalan dan peradaban semakin berkembang, tradisi dan inovasi terus melaju menapaki alur-alur masa yang semakin mengokohkan eksistensinya sebagai kemajuan di segala lini. Generasi sahabat tergantikan generasi tâbi'în, siklus berputar sesuai perjalanan era, lalu timbullah ijtihâd demi menerangkan al-haq dan memudahkan aplikasinya dalam tataran ibadah dan mu'âmalah. Mayoritas ulamâ' sepakat akan pentingnya ijtihâd sebagai sebuah kebutuhan asasi yang tidak bisa ditunda-tunda. Dan sebagai titian ke arah pengukuhan kepentingannya, perbedaan pendapat atau ikhtilâf dalam hal-hal yang bersifat far' $\hat{\imath}$, tidak bisa dihindarkan selama koridor kehati-hatian, kedewasaan, ke-legowo-an, dan responsibilitas terhadap pendapat madzhab lain dijaga dengan baik.

Ketika era madzâhib al-arba'ah muncul, tidak dipungkiri adanya ikhtilâf, namun yang perlu dicatat di sini bahwa pada masa itu tidak ada taqyîd keterjebakan semu pada madzhab tertentu sebagai bentuk fanatisme buta. Dalam kitab al-Burdah, al-Bushirî memberikan kesaksian :

Wakulluhum min rasûlillâhi multamisun

Gharfan min al-bahri aw rasyfan min al-diyâmi ${ }^{3}$

Dalam bahasa al-Bushiri, semua imam madzhab mengambil jatah "air" - nya dari sumber mata air yang sama, yaitu Nabî saw., sehingga tidak mungkin ada perbedaan esensial. Perbedaan pendapat hanya terjadi pada kulit luar dan lapisan muka, bukan pada masalah pokok dan substansi.

Persoalan muncul ketika pada generasi berikutnya benihbenih $t a^{\prime} a s s h u b a^{\prime} m a ̂$ mulai menampakkan bentuknya. Ada perasaan keunggulan dan superioritas pada masing-masing aliran yang dipicu

\footnotetext{
${ }^{2}$ Hadîts ini merupakan landasan utama bagi terbukanya pintu ijtihâd sampai hari kiamat. Dalam pandangan al-Suyuthi (w. 911 H.), kewajiban ijtihâd bagi ummat Islâm adalah konsekuensi logis dari nilai-nilai tajdîd yang diprediksikan Nabî akan muncul pada fase atau siklus seratus tahunan. Yang perlu digarisbawahi di sini adalah, ijtihâd dimungkinkan selama tidak ada nash. Jika sudah jelas ada nash sebagai panduan, maka ulama sepakat lâ ijtihâda ma'a al-nash. Periksa al-Syâtibî, Muqaddimah alMuwâfaqât al-Syâtib̂̂, vol. 1 (Beirut: Dâr al-Qalam, 1998), hlm. 13

3 Lihat al-Bajurî, Syarh al-Burdah (Surabaya: Pustaka al-Hidayah, t.th.), hlm. 24
} 
oleh mulai memudarnya rasa tawqîr atau hormat terhadap madzhab lain. Ditambah lagi, keengganan untuk mempelajari madzhab lain, sehingga sangat mudah untuk menyalahkan pendapat dan hasil ijtihâd mereka. Satu hal lagi yang menambah rumit persoalan, melihat gejala seperti itu, muncul madzhab baru yang sangat berbahaya, yaitu madzhab "anti madzhab" (lâ madzhabiyah) yang mengajak langsung merujuk pada al-Qur'ân dan al-Hadâts, padahal mereka jauh dari predikat mujtahid yang tentu saja diperlukan piranti khusus untuk mencapainya, seakan-akan mereka tidak tahu (atau pura-pura lupa?) bahwa para imam madzhab tidak ada seorang pun di antara mereka yang metodologinya menyimpang dari al-Qur'ân dan al-Sunnah.

\section{Esensi Ikhtilâf}

Dilihat dari sudut mana pun, ikhtilâf adalah sesuatu yang wajar, fitri, dan penting bagi dinamika kesejarahan ummat di muka bumi. Ia bukan sebuah momok yang menakutkan dan tak seorang pun yang mampu untuk membendung lajunya. Secara historis, Tuhan mengutus para Nabî dengan beberapa ikhtilâf dalam aplikasi ibâdah di antara mereka dari sisi syarî'ah-nya.

Di antara hal yang tidak bisa disangkal, para imam madzhab dan salaf al-shâlih tidak pernah membangun madzhabnya dengan pendapat yang bertentangan dengan al-Qur'ân dan al-Sunnah, sebagai sumber utama rujukan mereka. Ikhtilâf yang terjadi di antara mereka hanya pada "jalan menuju" kebenaran sebagai manifestasi pemahaman kedua sumber tadi. Bukan pada "kebenaran" nya dan bukan pada "kedua sumbernya". Bagi mereka, ikhtilâf bukan sarana untuk saling menyalahkan, menjebak, dan membenarkan pendapat sendiri, tetapi lebih pada upaya penalaran dan pencarian kebenaran dengan pijakan kedua sumber utama guna meretas solusi bagi dinamika permasalahan keseharian ummat. Tentu saja hal tersebut dibangun di atas pondasi yang kokoh yang berlabel kedaulatan dan keutuhan ummat (komunitas) Islâm. Jika ikhtilâf sudah menyemaikan benih-benih perpecahan dan pertentangan antar ummat, maka ia telah kehilangan esensi dan jatidiri.

Menukil pendapat al-Ghazâlî (w. 565 H.), Jalâl al-Dîn alSuyuthi (w. 911 H.) menegaskan bahwa kiblat para mujtahid adalah destinasi-destinasi (maqâshid) syarî'ah. Siapa pun yang memokuskan pada salah satunya, maka ia telah menuju pada kebenaran. 
Contohnya, ketika terjadi ikhtilâf antara Abû Bakar r.a dan Umar ibn al-Khattâb r.a dalam masalah pembagian harta pampasan perang, Abû Bakar memandang bahwa pembagian "bagi-rata" sehingga semua sahabat mendapat jatah yang sama adalah solusi yang adil dan menenteramkan, sedangkan Umar bersikukuh pada "madzhab"-nya sendiri bahwa mereka dibagi berdasar klasifikasi keutamaan dan senioritas. Alhasil, kedua khalîfah tersebut mempraktikkan pendapatnya di masa pemerintahannya masing-masing, sehingga kedaulatan ummat tetap bisa dijaga. ${ }^{4}$

Selain merupakan bentuk kasih sayang dan rahmat dari Tuhan bagi eksistensi dan dinamika Syarî'ah Islâm, ikhtilâf ulamâ' juga cermin dari kelenturan dan kesegaran hukum Islâm. Ia senantiasa hadir dalam berbagai fase perkembangan dan perputaran roda kehidupan dan kesejarahan ummat Islâm mulai dari jaman Nabî saw., para sahabat, tâbi'în, tâbi' al-tâbi'în, dan puluhan generasi sesudahnya hingga dunia kita sekarang ini. Selama kesatuan dan kedaulatan ummat bisa terjaga dengan baik, fanatisme bisa dihindari, dan api kebencian terhadap kelompok lain bisa dipadamkan, maka ikhtilâf bisa menjadi sebentuk toleransi yang mengejawantah dalam alur dinamisasi internal ummat Islâm. Nabî saw. telah memberikan lampu hijau dalam hal ini dengan sabdanya, "barang siapa yang shalat sebagaimana shalat kita, dan menghadap kiblat kita, memakan sembelihan kita, ia adalah muslim yang berada dalam tanggungan Allâh dan rasûlNya.." 5.

Di antara hikmah yang terkandung dalam rahasia penciptaan semesta adalah keanekaragaman yang terpola dalam semua makhluk, baik dalam mikrokosmos maupun makrokosmos. Perbedaan pemahaman, pemikiran, dan pendapat merupakan replika dari keragaman warna kulit, bahasa, agama, ras, suku, dan lain sebagainya. Dan jika ditelisik lebih jauh, perbedaan penciptaan sebagai hal yang fitri, juga mengindikasikan perbedaan buah pemikiran sebagai bagian tak terpisahkan dari hal yang fitrah tadi. ${ }^{6}$ Dan hal ini, sekali lagi, mendapatkan tempat dalam Islâm sebagai agama fitrah yang mengedepankan suhulah (gampang dan mudah)

\footnotetext{
4 Dikutip dari Majalah al-Râbithah edisi 475 (Januari 2006).

5 al-Bukhârî, Shahîh al-Bukharî, vol. 1 (Kairo: Dâr al-Salam, 1986), hlm. 342.

${ }^{6}$ al-Suyuthi, Atsar Ikhtilâf al-Fuqahâ' fî al-Syarî'ah (Beirut: Dâr al-Qalam, 1989), hlm. 23
} 
dan raf'ul haraj (meretas kesulitan dan beban). ${ }^{7}$ Selain al-Qur'ân, terdapat beberapa Hadîts Nabî yang menguatkan hal tersebut, yaitu: Pertama, Hadîts riwayat Bukhârî, "sesungguhnya agama ini mudah, jika ada yang ingin mempersulit, maka ia akan kalah. Maka baguskanlah perkataan, dekatkan yang jauh, dan berilah kabar gembira. ${ }^{8}$ Kedua, Hadîts wasiat kepada Muadz bin Jabal yang diriwayatkan oleh Bukhârî, "mudahkan, jangan mempersulit. Gembirakan, jangan menakuti." 9 Ketiga, Hadîts riwayat al-Nasa'i, "jauhilah sikap ghuluw (memberatkan diri dalam hal ibâdah) karena ummat sebelum kalian binasa karenanya". ${ }^{10}$

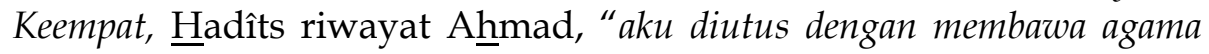
hanafiah yang samhah (toleran dan akomodatif)".11 Dengan beberapa karakteristik yang melekat, jelas ajaran Islâm memang diperuntukkan bagi manusia di semua tempat dan waktu dengan ragam perbedaan yang melekat sebagai fitrah penciptaan Ilâhiyah yang menginspirasikan Syarî’ah para Nabî sesuai dengan setting sosiokultural masing-masing.

\section{Ikhtilâf yang Membawa Rahmat}

Walaupun berasal dari akar kata yang sama, yaitu khalafa, ikhtilâf dan khilâf berbeda dalam makna dan aplikasi. Ikhtilâf berasal dari kata kerja bentuk lampau (fi'il mâdhî) ikhtalafa yang berarti berbeda. Sedangkan khilâf, yang berasal dari kata khalafa, bermakna menentang. Kata "khilâf" lebih berkonotasi pada pembangkangan dan ketidakpatuhan. Hal ini terlihat misalnya pada surat al-Nûr ayat 63 yang menggunakan kata yukhâlifûna bagi orang yang tidak mentaati perintah Allâh. Bukan yakhtalifûna, karena antara keduanya jelas ada perbedaan makna. Hal mana berbeda, misalnya, dengan penggunaan ikhtalâfu yang berarti berbeda pendapat dalam surat al-Baqarah ayat 213. Contoh lainnya adalah apa yang terjadi antara Nabî Nûh dan anaknya dalam peristiwa banjir, adalah khilâf.12 Sedangkan yang

\footnotetext{
${ }^{7}$ Lihat Al-Qur'ân, al-Baqarah (2): 185 dan 286; al-A'raf (7): 157, al-Mâidah (5): 6, alHajj (22): 78, dan an-Nisấ' (4): 28.

${ }^{8}$ Lihat al-Asqalani, Fath al-Bârî, vol. 1 (Kairo: Dâr al-Salam, 1986), hlm. 93.

9 Ibid., vol. 8, hlm. 60.

10 al-Nasâ'î, Sunan al-Nasâ'î, vol. 5 (Beirut: Dâr Ihyâ' al-Turats, 1997), hlm. 268.

11 Ahmad ibn Hanbal, al-Musnad, vol. 5 (Beirut: Dâr al-Fikr, t.th.), hlm. 266.

12 Al-Qur'ân, Hud (11): 42-43.
} 
terjadi antara Nabî Dawud dan Sulaymân dalam memutus perkara, adalah ikhtilâf. ${ }^{13}$

Perbedaan makna ikhtilâf dan khilâf dalam pengamatan alKafawi terjadi pada tiga titik. Pertama, dalam ikhtilâf tujuan tetap satu walaupun jalannya berbeda-beda. Sedangkan dalam khilâf, jalan dan tujuan sama-sama berbeda. Kedua, ikhtilâf memiliki landasan dalil dan pijakan hukum yang jelas, sedangkan khilâf tidak bersandar pada dalil atau hujjah. Ketiga, ikhtilâf merupakan buah dari rahmat, sunnah, dan kelenturan Syarî'ah, sedangkan khilâf adalah buah dari bid'ah dan egoisme. ${ }^{14}$

Dalam pandangan al-Suyuthi, ikhtilâf yang terjadi antara para fuqahâ' adalah rahmat dan keutamaan bagi ummat Islâm, walaupun hal ini hanya diketahui oleh para ulamâ' dan sedikit sekali yang percaya akan hal ini. Kaum juhalâ' bahkan cenderung mempertanyakan keabsahan madzhab-madzhab fiqh dengan asumsi bahwa Nabî saw. membawa satu Syarî'ah, lalu mengapa kemudian ada beberapa madzhab dalam fiqh dan teologi? Menurutnya, pertanyaan semacam ini adalah alur pikiran jâhiliyah yang mengacu pada prinsip egoisme dan fanatisme buta, karena tidak dilandaskan pada prinsip fitrah dan keniscayaan sejarah. ${ }^{15}$

Di masa sahabat, ikhtilâf sudah biasa terjadi namun tetap dalam bingkai saling menghormati dan tidak saling menyalahkan. Bahkan mereka saling mendoakan. Berdasar Hadîts yang telah populer di kalangan ulamâ' "ikhtilâfu ummatî rahmah"16, maka tidak ada alasan untuk tidak mengakui adanya ikhtilâf yang ditoleransi dalam Islâm. Karena yang menjadi acuan dalam ijtihâd yang kemudian menimbulkan ikhtilâf adalah maqâshid al-syarî'ah, maka di

\footnotetext{
13 Al-Qur'ân al-Anbiyâ' (21): 78-79.

14 Lihat Abul Baqa' al-Kafawî, al-Kulliyât, vol. 1 (Beirut: Dâr al-Fikr, t.th.), hlm., 79.

15 Periksa Jalâl al-Dîn al-Suyuthi, Jazil al-Mawâhib fî Ikhtilâf al-Madzâhib (Beirut: Maktabat al-Arabi, 1999), hlm., 23.

${ }^{16}$ Lihat al-Suyuthi, al-Jamî' al-Shaghir, vol. 1 (Beirut: Dâr al-Fikr, tt.), hlm. 13. Namun beberapa ulamâ', di antaranya Ibn al-'Arabî mengatakan bahwa Hadîts ini dha'îf menurut sebagian pakar Hadîts. Walaupun dari segi makna tidak berseberangan

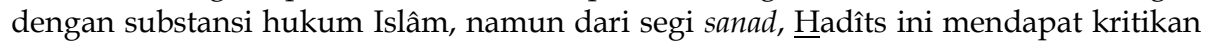
tajam sehingga mendudukkannya ke dalam kategori Hadîts dha'îf. Sedangkan teori yang populer di kalangan muhadditsin, jika suatu sanad didukung oleh katsratu althurûq, maka ia menjadi hasan. Dan menurut Imam Ahmad, Hadîts dha'îf bisa dipakai dalam kerangka fadhâil al-a'mâl.
} 
kalangan ulama muncul adagium yang berbunyi "takhtalif 'uqûlunâ walâ takhtalif qulûbunâ" (akal/metodologi kita beda, namun hati kita sama). Seperti usaha taqarrub seorang hamba kepada Tuhannya yang bisa dilakukan dengan berbagai media. ${ }^{17}$

Pakar ushûl al-figh yang sering dijadikan rujukan dalam hal maqâshid al-syarî'ah, al-Syatibi, mengatakan bahwa seandainya pintu ijtihâd ditutup dan ikhtilâf dilarang, maka para mujtahid akan merasakan kesempitan yang luar biasa akibat disharmoni antara asumsi mereka dan beban (taklîf) yang ditanggung. Kalau ini terjadi, maka telah berlangsung pembebanan yang tidak semestinya yang tidak senafas dengan destinasi syarî'ah. Maka Allâh memberikan keleluasaan bagi mereka untuk ber-ikhtilâf dalam hal yang bersifat furu' tersebut. ${ }^{18}$

Satu hal yang patut dicermati dalam ikhtilâf yang terjadi pada masa salaf al-shâlih adalah bahwa selain mereka tidak mencela dan menyalahkan pendapat orang lain, mereka juga tidak menisbatkan hasil ijtihâd mereka kepada diri sendiri dan tidak menafikan kebenaran yang lain. Dengan kata lain, atmosfer ijtihâd benar-benar kental terasa. Contoh kecil dalam hal ini adalah apa yang dikatakan oleh khalîfah Umar bin Abd al-Azîz, "aku tidak suka jika para sahabat Nabî saw. tidak berbeda pendapat, seandainya mereka satu kata, maka ummat akan berada dalam kesempitan. Mereka adalah para imam yang diikuti. Maka siapa pun yang mengikuti salah seorang dari mereka, ia telah mengikuti sunnah" 19.

Contoh paling konkrit dalam hal keluasan ikhtilâf dan ijtihâd adalah apa yang dilakukan Imâm Mâlik (w. 179 H.). Ketika magnum opus-nya, al-Muwattha', diminta oleh penguasa untuk dijadikan buku wajib sebagai pijakan dasar hukum Islâm berskala nasional (bahkan internasional jika merujuk pada sistem khilâfah), ia menolak dengan alasan untuk menciptakan keleluasaan dalam bermadzhab dan berlaku fair dalam semua proses ke arah pengembangan dan dinamisasi hukum Islâm, sehingga tidak terjadi monopoli kebenaran (truth claim).

17 Periksa al-Syâtibî, al-Muwâfaqât, vol. 4 (Beirut: Dâr al-Qalam, 1995), hlm. 223.

18 Lihat al-Syâtibî, al-I'tishâm, vol. 2 (Beirut: Dâr al-Fikr, 1987), hlm. 432.

19 Lihat Ibnu Rajab al-Hanbali, Jamî’ Bayân al-Ilmi wa Fadhlihi, vol. 2 (Beirut: Dâr alFikr, t.th.), hlm. 80 . 
Mengutip Muhammad Awwamah, banyaknya aliran dan madzhab dalam Islâm sebagai buah dari eksistensi Syarî'ah membawa manfaat yang signifikan kepada ulil amri (penguasa) untuk memilih mana yang terbaik bagi kemaslahatan bangsa. Hampir semua literatur fiqh dari semua aliran membolehkan taqlîd, talfiq, dan pindah madzhab. Hal ini jauh-jauh sudah dipraktikkan oleh ulama salaf ketika mereka berada dalam batas wilayah "teritorial" madzhab lain, sehingga bentuk tenggang rasa terhadap madzhab lain bisa diaplikasikan dengan baik di wilayah masing-masing. ${ }^{20}$

\section{Ikhtilâf dalam Medan Ijtihâd}

Jika ada pendapat yang mengatakan bahwa banyaknya ikhtilâf fuqahâ' yang terjadi di medan ijtihâd adalah titik kelemahan fiqh dan cermin dari kontradiksi syarî́ah, maka sudah semestinya pendapat semacam itu dikaji secara matang dalam perspektif historis dan empiris. Tersebab, ia muncul dari realita kehidupan ummat Islâm yang carut-marut akibat tidak adanya kedaulatan yang utuh di hampir semua sektor kehidupan. Namun jika dikembalikan ke pola dasar dan karakteristik Syarî'ah yang fleksibel dan akseptabel, maka ia akan berbalik ke arah yang sebenarnya di mana fitrah dan keniscayaan sejarah telah menjadi sumbu utamanya.

Suburnya nuansa figh Islâm dalam ikhtilâf dan pencabangan (tafrî') telah selaras dengan disparitas kemampuan masing-masing pengkaji dan mujtahid untuk meng-istinbâth hukum-hukumnya demi kemaslahatan dan kesejahteraan hidup manusia di dunia dan akhirat sebagai tujuan pokoknya. Deferensiasi kemampuan akal dan penalaran para imam madzhab dan para fuqahấ secara umum dalam mengeksplorasi dan mengelaborasi hukum tentu saja sudah sesuai dengan ruh atau spirit syarî'ah yang bersifat murunah dan kondisional. Persis seperti kemampuan para dokter dan paramedis yang senantiasa dituntut untuk bisa menangani dan menyembuhkan berbagai macam penyakit yang datang silih berganti sesuai dengan perkembangan jaman. Dalam hal ini, ijtihâd mereka tentu mengalami

20 Syaykh Muhammad Awwamah, Adab al Ikhtilâf fâ Masâil al-Ilm wa al-Dîn (Kairo: Dâr al-Syuruq, 1994), hlm. 75. Sedangkan contoh-contoh "pindah madzhab" dan talfíq, baca Ibn Taymiyah, Majmûu' Fatawâ, vol. 20 (Beirut: Dâr al-Qalam, 1995), hlm. 364. 
ikhtilâf dan pasang-surut juga, namun habitat di luar mereka tidak bisa menyalahkan begitu saja karena bukan bidang garapannya.

Dalam bahasa yang lugas, al-Syathibi mengatakan bahwa masalah furu' atau juz'iyyât dari agama ini sangat terbuka untuk dikaji dan di pra-asumsikan. Karena untuk sampai pada teori baku, kita harus "berputar" pada poros asumsi dulu. Dalam hal inilah peran akal sangat diperlukan. Tidak mungkin, demi akseptabilitas ajaranNya, Allâh membuat aturan yang rigid dan kaku, terperinci, detil dan tuntas. Karena semakin rinci sebuah aturan, semakin tertutup ruang gerak dinamika penalaran dan pengkajian ke arah masa depan. ${ }^{21}$ Dalam tataran inilah, ilmu ushûl al-fiqh yang digagas al-Syâfi'î menemukan relevansi dan koneksinya dengan teori-teori dasar yang bersifat umum dan mujmal. Teori dasar yang dimaksud adalah teori 'âmm-khâs, mujmal-mufashshal, naskh, klasifikasi hukum, dan sebagainya. Memang dalam masa awal kesejarahannya, ijtihâd tidak dimungkinkan pada Syarî'ah terdahulu mengingat usianya yang masih "bayi" dan persoalan metodologi tidak memerlukan perangkat akal dan penalaran karena setiap persoalan waktu itu langsung mendapat "juklak" dari Allâh. Hikmahnya, kemanusiaan berjalan menuju kedewasaan dan berproses sesuai dengan fitrah dan siklus alamiah. Sebagai penutup risâlah, syarî'ah Nabî Muhammad saw. dipungkasi dengan instrumen ijtihâd sebagai solusi atas berbagai persoalan kehidupan dan penanda kedewasaan usia kemanusiaan yang telah berjalan sesuai kodratnya sejak awal penciptaan, setelah tawaqquf atau inqitha- nya wahyu.

Dalam menafsirkan surat al-Mâidah ayat 48, "Dan jika Allâh mau, ia menjadikan kamu satu ummat saja", Syaykh Rasyîd Ridhâ mengatakan, syarî́ah Islâm dibangun di atas dasar kemerdekaan insani yang identik dengan usia kematangan dan kedewasaan serta alur kebangkitan metode berfikir. Karenanya sedikit sekali yang menyangkut hukum dunia. Karenanya, ijtihâd diwajibkan sebagai kelaziman "orang dewasa yang mengurus urusannya sendiri" sehingga tidak mungkin diseragamkan sebagai satu ummat. ${ }^{22}$

Pada titik ini, sebenarnya peran mujtahid dan muftî sangat strategis sebagai wakil Nabî dalam tiga hal. Pertama, ia merupakan

21 al-Syâtibî, al-I'tishâm, hlm. 168.

22 Rasyîd Ridhâ, Tafsîr al-Manâr, vol. 4 (Kairo: Dâr al-Salam, t.th.), hlm. 446. 
pewaris $\mathrm{Nab}^{23}$ dalam bidang ilmu syarî'ah. Kedua, ia mengajarkan, mendidik, mengajak, menyeru, dan menyampaikan kebenaran (ajaran Islâm). Berkaitan dengan hal ini, ia bersabda, "hendaklah orang yang menyaksikan dan mendengarkanku, menyampaikan kepada yang tidak hadir dan belum mendengar"24. Ketiga, ia sebagai wakil Nabî dalam mengistinbâth hukum dari sumbernya. Pendeknya, instrumen ijtihâd dalam Islâm adalah sebuah kasyf atau penyingkap tirai kegelapan hukum sebagai penjabaran syarî'ah, dan bukan sebagai usaha untuk membuat syarî'ah baru. Karena ia adalah khashâis atau kekhususan yang diberikan Allâh bagi syarî'ah ummat ini sebagai penutup risâlah samawi. ${ }^{25}$

Perlu sekali lagi ditegaskan di sini bahwa ikhtilâf hanya berlaku dalam tataran figh atau pemahaman. Sedangkan dalam Syarî'ah sendiri, tidak ada ikhtilâf. ${ }^{26}$. Ikhtilâf dalam medan ijtihâd, jelas bukan sebuah kontradiksi apalagi sebuah bentuk kebatilan atau kekurangan. Asumsi semacam ini lahir dari kerancuan pemahaman kata syarî'ah dan figh. Syarî'ah adalah kumpulan hukum yang bersifat i'tiqâdiyah dan 'amaliyah dalam bentuk wahyu yang diturunkan kepada Nabî saw. yang merefleksikan teks-teks suci yang bersifat tetap dan universal. Tidak ada ikhtilâf dalam hal ini. Sedangkan figh adalah kumpulan hukum praktis sebagai hasil pemahaman mujtahid terhadap dalil syarî'ah melalui metode istinbâth atau ijtihâd secara umum. Di sinilah banyak terjadi ikhtilâf sebagai perbedaan pemahaman karena adanya ketidaksamaan akal dalam memahami konteks sebuah dalil. Maka tempat kembalinya ikhtilâf bukan pada teks, tapi pada pemahaman.

\section{Sebab-sebab Timbulnya Ikhtilâf}

Dalam literatur perbandingan madzhab figh, banyak dijumpai sebab-sebab timbulnya perbedaan pendapat antara fuqahâ' sebagai buah dari keluwesan syarî́ah. Sedikitnya ada delapan poin yang akan disebutkan di sini :

\footnotetext{
${ }^{23}$ Hal ini disabdakan sendiri oleh Nabî, "ulamâ' adalah pewaris para Nabî. Mereka tidak mewariskan dinar dan dirham, tapi mewariskan ilmu (agama)" (HR. Abu Dawud dan alTirmidzî)

24 al-Bukhârî, Shahîh $\underline{h}$ hlm. 354

25 Untuk lebih jelasnya, periksa al-Syâtibî, al-Muwâfaqât, vol. 4, hlm. 467.

${ }^{26}$ Lihat al-Qur'ân, al-Nisâ' (4): 82.
} 
1. Ikhtilâf dalam hal bacaan atau qira'ah, seperti lafadz "arjulakum" dan "arjulikum",27 di mana perbedaan bacaan antara keduanya berdampak pada perbedaan persepsi seputar kewajiban mencuci kaki atau hanya sekedar membasuhnya dalam wudhu'. Begitu juga bacaan "yathhurna" dan "yatthahharna" 28 yang berimplikasi pada ikhtilâf seputar boleh tidaknya menggauli istri sebelum mandi) karena sudah suci dari siklus haidnya, atau harus menggaulinya sesudah mandi, dan seterusnya.

2. Perbedaan tentang legalitas dan kehujjahan qira'ah âhâd, seperti yang telah memicu polemik antara jumhur fuqahâ' dan kalangan Hanafiyah pada qira'ah Ibnu Mas'ûd (tsalâtsata ayyâmin mutatâbi'ât) yang berakibat pada perbedaan wajibnya kesinambungan puasa kaffarât sumpah selama tiga hari berturut-turut.

3. Kealpaan atau kelupaan akan sebuah Hadîts, seperti yang terjadi pada Abû Bakar al-Shiddîq yang lupa Hadits yang menerangkan berapa bagian yang diperoleh nenek dari harta warisan, sampai diberitahu oleh Mughîrah bin Syu'bah dan Muhammad bin Maslamah, akibat kesibukannya mendampingi Nabî dalam mengurusi negara.

4. Perbedaan tentang ketetapan sebuah Hadîts tertentu, seperti penolakan Umar bin al-Khattâb terhadap Hadîts yang diriwayatkan Fâtimah binti Qays tentang hak wanita yang ditalak tiga atas rumah dan nafkah, akibat keraguan Fâtimah sendiri terhadap Hadîts yang diriwayatkannya, apakah ia hafal atau lupa sebagian teksnya.

5. Perbedaan dalam hal pemahaman teks. Hal ini bisa disebabkan karena beberapa faktor: Pertama, adanya persekutuan makna ayat dalam al-Qur'ân, seperti yang terjadi pada kalimat "qurü" di mana sebagian fuqahâ" memaknainya dengan masa suci, sementara yang lain mengartikan haid. Sedangkan kalimat itu sendiri bermakna keduanya. Kedua, adanya persekutuan makna dalam huruf al-Qur'ân, seperti huruf $b a^{\prime}$ dalam kalimat "biru' $\hat{s}$ sikum" yang diartikan sebagai

${ }^{27}$ Ibid., al-Mâidah (5): 6.

${ }^{28}$ Ibid., al-Baqarah (2): 222. 
$b a^{\prime}$ zaidah oleh sebagian fuqahấ $\hat{a}^{\prime}$ dan dimaknai sebagai $b a^{\prime}$ lil ilshaq oleh sebagian yang lain serta ada juga yang memaknainya sebagai $b a^{\prime}$ li al-tab'idh. Sehingga dengan variasi makna tersebut berakibat pada terjadinya ikhtilâf dalam hal mengusap rambut ketika berwudhu', antara yang mewajibkan mengusap semua rambut, sebagian, dan yang harus menjalanratakan tangan pada kepala. Ketiga, adanya makna ganda dalam sebuah kalimat, seperti ayat yang menerangkan siapa sebenarnya yang dimaksud dengan "biyadihî 'uqdatun nikâh", antara wali si wanita atau suaminya. Keempat, adanya kerancuan persepsi dalam sebuah ayat apakah masuk kategori haqîqah atau majâz, seperti kalimat "lâmastum al-nisâ" jika dikatakan majâz (persetubuhan), maka menyentuh wanita tidak membatalkan wudhu'. Sedangkan jika dikatakan sebagai haqîqah, maka bermakna sebaliknya.

6. Perbedaan dalam perlakuan terhadap Hadîts tertentu, antara posisinya sebagai wahyu dan sebagai kebijakan. Contohnya adalah persepsi terhadap Hadits yang mengatakan bahwa orang yang menggarap tanah tak bertuan maka dialah pemiliknya. Apakah Hadîts tersebut berfungsi sebagai tasyrî́ yang notabene wahyu, ataukah hanyalah kebijakan kepala negara demi kesejahteraan rakyatnya.

7. Ikhtilâf dalam sumber-sumber hukum yang dijadikan pijakan dasar istinbâth. Sebagaimana diketahui, sumber hukum primer adalah al-Qur'ân, al-Sunnah, ijmâ' dan qiyâs. Sedangkan sumber sekunder adalah istihssân, mashlahah mursalah, 'urf, qawl shahâbah, istishab, syar'u man qablanâ, dan sadd al-dzarâ'ah. Tidak ada ikhtilâf dalam kehujjahan sumber primer. Namun pada sumber sekunder, terdapat ikhtilâf yang berkepanjangan, baik dalam tingkatannya maupun legalitasnya.

8. Perbedaan dalam teori-teori pokok yang bersifat semantik, seperti teori takhsîs, mafhûm mukhâlafah, muthlaq-muqayyad, fawr-tarakhî dan sebagainya yang berakibat pada ikhtilâf hasil produk ijtihâd yang berbentuk hukum, antara wajib, sunnah, mubah, dan sebagainya. 


\section{Dampak Ikhtilâf bagi Kedaulatan Ummat}

Sebagai manifestasi dari sifat taysîr yang merekomendasikan dilakukannya ijtihâd demi kemaslahatan dan terjawabnya persoalanpersoalan kekinian, seleksi ketat bagi pelaku ijtihâd layak mendapatkan apresiasi yang tinggi, mengingat hal ini mengantarkan ijtihâd pada tempatnya yang hakiki sebagai buah syarî'ah. Dengan begitu, ikhtilâf sebagai mata-rantai yang tak terpisahkan dari ijtihâd juga tidak akan menimbulkan polemik yang tidak sehat karena dilakukan oleh ahlinya. Para mujtahid, bagaimanapun, adalah pahlawan bagi ummat. Karena merekalah yang mampu mengarahkan instrumen ijtihâd.

Dampak positif yang nyata dan dapat dirasakan dari adanya ikhtilâf dalam medan ijtihâd adalah kebebasan untuk memilih madzhab tertentu bagi negara dan bagi masyarakat awam. Tidak ada paksaan untuk mengikuti imam madzhab tertentu dan tidak dibenarkan memaksakan madzhab tertentu kepada ummat. Tentu pemerintah dan negara diharapkan berlaku bijak dalam hal ini, dengan melihat aspek sosio-kultural dan geografis yang relevan atau munâsib bagi bangsa. Kondisi negara-negara teluk di Timur-Tengah mungkin memang layak dipayungi dengan madzhab Hanbalî dalam bidang figh. Sebagaimana mayoritas bangsa muslim di Asia Tenggara yang memangku madzhab Syâfi'â. Semua bebas untuk menganut madzhab apapun dan di manapun asal toleransi dan objektifitas dijaga dengan baik.

Jika terjadi pemaksaan kehendak dalam bermadzhab, maka sesungguhnya telah terjadi distorsi penyembahan Allâh yang tidak pada tempatnya. Kesempitan yang luar biasa dalam syarî́ah karena hanya ada satu jalan yang harus dilewati oleh sekian juta orang. Tujuan semua pelaku ijtihâd adalah kebenaran, bukan ikhtilâf yang kemudian terjadi. Sedangkan ikhtilâf yang terjadi di antara para fâqih dan imam madzhab akan berdampak positif bagi para konsumen hukum Islâm (masyarakat awam) karena banyaknya pilihan sehingga mereka bisa menyesuaikan kondisi masing-masing dengan fatwâ dan hasil ijtihâd para imam.

Ikhtilâf hanya akan berbuah lebat jika ummat menjaga adqb $i k h t i l a ̂ f$ berupa rasa hormat dan toleransi antar madzhab serta adanya perasaan persaudaraan dan ukhuwwah yang menjelma dalam sikap dan perilaku sehari-hari. Di sinilah sebenarnya kedaulatan ummat 
diuji dari masa ke masa. Di masa sahabat dan tabi'in, ikhtilâf adalah hal yang biasa terjadi. Namun karena tujuan yang memayungi mereka sama, yaitu al-hudâ atau petunjuk Ilâhi, maka ia hanya akan menambah rasa kebersamaan (i'tilâf) dan bukannya khilâf yang berkepanjangan. Karenanya, sebagai penghargaan dan apresiasi kepada para mujtahid, Islâm memberikan poin tersendiri, bagi mujtahid yang benar (sesuai dengan destinasi syarî́ah), maka mereka mendapat dua pahala, sedangkan yang sebaliknya, tetap mendapat satu pahala. Hal ini bisa kita lihat secara jelas dalam kisah Nabî Dawud dan putranya, Nabî Sulaymân, yang berbeda pendapat dalam suatu perkara yang disitir Allâh dalam surat al-Anbiyấ ayat 78 . Pendapat Sulaymân lebih mengenai sasaran tapi Allâh tidak menyalahkan Dawud dan membodohkannya, tapi mengatakan kalau keduanya telah diberi ilmu pengetahuan dan hukum (wakullan âtaynâ hukman wa ilman). Oleh karenanya, jika kita membuka kembali lembaran-lembaran literatur sejarah, akan menemukan bahwa ikhtilâf yang terjadi antara para ulamâ' sebagai hal yang wajar dan menenteramkan karena pelakunya memahami dengan baik $a d a b$ ikhtilâf.

Namun, lepas dari semua itu, sejarah Islâm pernah diisi oleh rekaman dampak ikhtilâf yang tidak sehat, bahkan menimbulkan luka yang sangat dalam. Hikmah yang dapat diambil dari peristiwa tersebut adalah agar kejadian semacam ini tidak terulang lagi di masa kini dan masa yang akan datang. Perpecahan dan pertentangan adalah hal yang sangat rentan terjadi pasca-ikhtilâf. Ketika dua hal ini terjadi, maka seperti yang dikatakan Allâh dalam al-Qur'ân, akan ada fasyal (kegagalan) dan tadzhabâa rîhukum (hilang wibawa) dalam ummat ini. Fanatisme buta (ta'asshub a'mâ) sebagai bias dari ikhtilâf menimbulkan kerugian yang luar biasa bagi kaum Muslim berupa masuknya kekuatan asing dan pihak musuh yang akan dengan gampang memancing di air keruh, sehingga kebencian sesama muslim akan tumbuh subur, timbulnya perdebatan dan percekcokan berkepanjangan, dan hal-hal negatif lainnya yang berakibat pada mandulnya kemajuan bahkan mundurnya kaum Muslim di semua lini seperti yang sedang kita rasakan sekarang. 


\section{Penutup}

Setelah pemaparan singkat di atas, sebagai bentuk klimaks dalam mengakhiri tulisan ini, penulis hendak memberikan kesimpulan dan rekomendasi (tawshiyah) untuk bahan renungan dan pemikiran berkelanjutan di masa yang akan datang. Pertama, ikhtilâf dalam masalah-masalah ijtihâdiyah adalah hal yang wajar dan lumrah sebagai akibat dari deferensiasi kemampuan akal dan pemahaman. Kedua, dampak positif ikhtilâf sebagai buah syarî'ah akan terus eksis selama adab ikhtilâf dijaga. Ketiga, mereduksi dampak negatif ikhtilâf dianjurkan dengan mengecilkan volume $t a^{\prime} a s s h u b$ dan hal negatif lainnya. Keempat, penutupan pintu ijtihâd adalah hal yang bertentangan dengan syarîah karena berseberangan dengan akseptabilitas ajaran Islâm dan keniscayaan sejarah. Sedangkan persoalan-persoalan kehidupan akan terus berpacu dengan waktu menunggu untuk diselesaikan secepatnya. Kelima, terbukanya pintu ijtihâd bukan berarti terbuka selebar-lebarnya sehingga memungkinkan yang bukan ahlinya untuk leluasa masuk, tapi dengan seleksi yang ketat sesuai dengan prosedur yang telah ditentukan dan disepakati para ulama sebagaimana termaktub dalam kitab-kitab ushul-fiqh. Keenam, riset dan pusat-pusat studi hendaknya dijadikan prioritas bagi pihak berwenang dalam program-program kemaslahatan, kesejahteraan, dan pencerahan ummat. Upaya ini dalam kerangka penciptaan khayru ummah yang kini semakin menjauh dari titik realita. Ketujuh, diperlukan kesadaran yang mendalam dari semua pihak tentang apa yang sedang terjadi sekarang ini menyangkut kondisi ummat Islâm yang semakin hari semakin tidak menemukan bentuk kedaulatan dalam bentuk apapun, baik dalam percaturan nasional maupun internasional, baik dari segi politik, ekonomi, sosial, budaya, dan lainnya. Karenanya, kondisi ini jangan lantas diperparah dengan ikhtilâf internal yang bersifat negatif dan merugikan. Sehingga ikhtilâf yang terjadi di area dan madzhabmadzhab figh bisa benar-benar menjadi rahmat dan bukan sebaliknya. Wa Allâh a'lam bi al shawâb

\section{Daftar Pustaka:}

Asqalani, al-. Fath al-Bârî, vol. 1. Kairo: Dâr al-Salam, 1986. 
Abdul Mukti Thabrani

Awwamah, Syaykh Muhammad. Adab al Ikhtilâf fâ Masâil al-Ilm wa alDîn. Kairo: Dâr al-Syuruq, 1994.

Bajurî,al- .Syarh al-Burdah. Surabaya: Pustaka al-Hidayah, t.th.

Bukhârî,al-.Shahîh al-Bukharî, vol. 1. Kairo: Dâr al-Salam, 1986.

Hanbal,Ahmad ibn. al-Musnad, vol. 5. Beirut: Dâr al-Fikr, t.th.

Hanbali, Ibnu Rajab al-. Jamî’ Bayân al-Ilmi wa Fadhlihi, vol. 2. Beirut: Dâr al-Fikr, t.th.

Kafawî,Abul Baqa' al- .al-Kulliyât, vol. 1. Beirut: Dâr al-Fikr, t.th.

Muslim, Imâm. Shahîh Muslim, vol. 2. Kairo: Dâr al-Salam, 1987.

Nasâ'î, al-. Sunan al-Nasâ'̂̂, vol. 5. Beirut: Dâr Ihyâ' al-Turats, 1997.

Ridhâ, Rasyîd. Tafsîr al-Manâr, vol. 4. Kairo: Dâr al-Salam, t.th.

Suyuthi, Jalâl al-Dîn al-. al-Jamî̀ al-Shaghir, vol. 1. Beirut: Dâr al-Fikr, t.th.

------. Atsar Ikhtilâf al-Fuqahấ fî̀ al-Syarî'ah. Beirut: Dâr al-Qalam, 1989.

------. Jazil al-Mawâhib fî Ikhtilâf al-Madzâhib. Beirut: Maktabat al-Arabi, 1999.

Syâtibî, al-. al-I'tishâm, vol. 2. Beirut: Dâr al-Fikr, 1987.

-----. Muqaddimah al-Muwâfaqât al-Syâtib̂̂, vol. 1 dan 4. Beirut: Dâr alQalam, 1998.

Taymiyah, Ibn. Majmî̀' Fatawâ, vol. 20. Beirut: Dâr al-Qalam, 1995. 